\title{
KEEFEKTIFAN PRAUJIAN NASIONAL MATEMATIKA \\ TAHUN AKADEMIK 2004/2005 \\ (Studi Kasus di SMK Negeri dan Swasta di Jakarta Selatan 06)
}

\author{
Abdul Hoyyi \\ Staf Pengajar Program Studi Statistika FMIPA UNDIP
}

\begin{abstract}
National pre-exam is one way of the evaluation to the student's ability. Through national pre-exam, it would get information how far the student's preparation to have national exam. National pre-exam is expected to improve student's score on national exam. In addition, national pre-exam is expected can be used to evaluate student's preparation and it can predict national examination score. The improving of student's achievement depends on the way the analysis of change of national examination achievement distribution and description statistics analysis national examination score. The statistics of McNemar's test is used to know student's preparation, because the sample is dependent. Correlation and simple linier regression analysis used for analysis prediction. The increase of national examination score not always the effect of pre-national examination. The pre-national examination can't be used to estimate student's preparation. The probability student that pass the national exam is higher than pre-national exam. It is caused by pre-national exam is more difficult than national exam through the same passing limit. The score of national exam prediction is obtained confidence limit wide enough. Therefore, the variant national of examination achievements is quite large.
\end{abstract}

Key words: National Pre-exam, National Exam, Description Analysis, McNemar's Test; Prediction

\section{Pendahuluan}

Setiap akhir tahun akademik pemerintah selalu mengadakan Ujian Nasional (UN) bagi siswa tingkat akhir Sekolah Menengah Pertama (SMP), Sekolah Menengah Atas (SMA) dan Sekolah Menengah Kejuruan (SMK). Siswa dikatakan berhasil pada tingkatan masing-masing sekolah bila siswa tersebut lulus pada UN. Persentase kelulusan UN pada SMK di Jakarta Selatan 06 sebesar 71,11\%. Persentase ini terendah dibandingkan dengan persentase kelulusan SMK di wilayah lainnya. Berdasarkan keterangan dari Ketua Rayon Jakarta Selatan 06, hanya di SMK Jakarta Selatan 06 saja yang melaksanakan Pra-UN secara serentak. Sementara SMK di wilayah lainnya mayoritas melaksanakan Pra-UN secara internal. Berdasarkan informasi perlu untuk diteliti sejauh mana manfaat Pra-UN ini bagi lingkungan SMK di Jakarta Selatan 06 terhadap peningkatan nilai UN siswa khususnya bidang studi Matematika. Selain untuk meningkatkan nilai UN, soal Pra-UN ini diharapkan efektif artinya mampu menilai kesiapan siswa dan bisa digunakan sebagai gambaran nilai siswa pada UN . Kesiapan siswa artinya siswa yang lulus Pra-UN akan berpeluang lulus pada UN juga, sebaliknya siswa yang tidak lulus UN akan berpeluang tidak lulus pada UN. Selain itu soal Pra-UN ini diharapkan dapat digunakan sebagai prediksi bagi soal UN, artinya nilai yang didapat siswa pada Pra-UN tidak jauh berbeda dengan nilai yang didapat pada UN sebenarnya nanti. Dengan demikian permasalahannya apakah Pra-UN dapat digunakan untuk menilai kesiapan siswa dalam menghadapi UN dan 
juga apakah nilai Pra-UN yang dicapai siswa dapat digunakan untuk meramalkan atau memprediksi nilai UN. Adapun tujuan yang hendak dicapai melalui penelitian ini adalah:

1. Mengetahui apakah Pra-UN dapat meningkatkan nilai UN siswa.

2. Mengetahui apakah Pra-UN dapat digunakan untuk menilai kesiapan siswa dalam menghadapi UN.

3. Mengetahui apakah nilai Pra-UN yang dicapai dapat digunakan untuk meramalkan atau memprediksi nilai UN.

\section{Tinjauan Pustaka}

\subsection{Uji McNemar Sampel Tak Bebas dalam Tabel 2x2}

Penggunaan sampel yang sama untuk dua perlakuan namun dalam waktu yang berbeda. Kasus sini dikatakan kedua sampelnya tidak bebas (Steel \& Torrie, 1980). Misalnya dua perlakuan tersebut berkategori sukses atau gagal dan ditabelkan sebagai berikut:

Tabel 1. Tabulasi silang $2 \times 2$ untuk sampel tidak bebas

\begin{tabular}{|c|c|c|c|}
\hline \multirow{2}{*}{ Perlakuan pertama } & \multicolumn{2}{|c|}{ Perlakuan kedua } & \multirow{2}{*}{ Total } \\
\cline { 2 - 3 } & Sukses $\left(\mathrm{S}_{2}\right)$ & Gagal & \\
\hline Sukses $\left(\mathrm{S}_{1}\right)$ & $n_{11}$ & $n_{12}$ & $n_{1 .}$ \\
\hline Gagal $\left(\mathrm{G}_{1}\right)$ & $n_{21}$ & $n_{22}$ & $n_{2 .}$ \\
\hline Total & $n_{.1}$ & $n_{.2}$ & $n_{. .}$ \\
\hline
\end{tabular}

Hipotesisnya adalah:

$\mathrm{H}_{0}: P\left(S_{1}\right)=P\left(S_{2}\right)$

$\mathrm{H}_{1}: P\left(S_{1}\right) \neq P\left(S_{2}\right)$

Keterangan:

$P\left(S_{1}\right)$ : Peluang sukses pada perlakuan pertama.

$P\left(S_{2}\right)$ : Peluang sukses pada perlakuan kedua.

Tabel 2. Nilai Harapan Kategori

\begin{tabular}{|c|c|c|}
\hline \multirow{2}{*}{ Kategori } & \multicolumn{2}{|c|}{ Frekuensi } \\
\cline { 2 - 3 } & $\begin{array}{c}\text { Kenyataan } \\
(o)\end{array}$ & $\begin{array}{c}\text { Harapan (bila Ho benar) } \\
(e)\end{array}$ \\
\hline$S_{1} \cap G_{2}$ & $n_{12}$ & $\frac{n_{12}+n_{21}}{2}$ \\
\hline$G_{1} \cap S_{2}$ & $n_{21}$ & $\frac{n_{12}+n_{21}}{2}$ \\
\hline Jumlah & $n_{12}+n_{21}$ & $n_{12}+n_{21}$ \\
\hline
\end{tabular}

Keterangan:

$S_{1} \cap G_{2}$ : Lulus perlakuan pertama dan gagal perlakuan kedua.

$G_{1} \cap S_{2}$ : Gagal perlakuan pertama dan lulus perlakuan kedua. 
Statistik uji yang digunakan:

$$
\begin{aligned}
& \chi^{2}=\sum \frac{(o-e)^{2}}{e}=\frac{\left(n_{12}-\frac{n_{12}+n_{21}}{2}\right)^{2}}{\frac{n_{12}+n_{21}}{2}}+\frac{\left(n_{21}-\frac{n_{12}+n_{21}}{2}\right)^{2}}{\frac{n_{12}+n_{21}}{2}} \\
& \chi^{2}=\frac{\left(n_{12}-n_{21}\right)^{2}}{n_{12}+n_{21}}, \text { dengan derajat bebas sama dengan } 1 .
\end{aligned}
$$

Menurut Agresti \& Finlay (1986) persamaan (1) dikenal dengan nama uji McNemar (McNemar's test ). Sedangkan menurut McNemar (1969) bila nilai $n_{12}+n_{21}<20$, maka perlu dilakukan koreksi dengan persamaan:

$$
\chi^{2}=\frac{\left(\left|n_{12}-n_{21}\right|-1\right)^{2}}{n_{12}+n_{21}}
$$

Kriteria keputusannya adalah bila $\chi^{2}>\chi_{\alpha}^{2}$, maka hipotesis nol ditolak.

\subsection{Keterandalan Model}

Keterandalan dari model $Y_{i}=\alpha+\beta X_{i}+\varepsilon_{i}$, dengan $Y$ adalah peubah terikat, $X$ adalah peubah bebas, dapat dilihat dari kemampuan model menerangkan keragaman nilai peubah $Y$. Ukuran ini sering disebut koefisien determinasi. Semakin besar nilai koefisien determinasi berarti model semakin mampu menerangkan keragaman nilai peubah $Y$. Dalam Draper \& Smith (1981) selang kepercayaan $(1-\alpha) 100 \%$ bagi nilai individual $Y_{0}$ untuk suatu nilai $X_{0}$ tertentu dirumuskan :

$$
\hat{Y}_{0} \pm t_{(d b, \alpha / 2)}\left(1+\frac{1}{n}+\frac{\left(X_{0}-\bar{X}\right)^{2}}{\sum\left(X_{i}-\bar{X}\right)^{2}}\right)^{1 / 2} s
$$

Keterangan:

$$
\begin{array}{lll}
\hat{Y_{0}}=\text { nilai dugaan individu } & , X=\text { peubah bebas } & \\
X_{0}=\text { nilai individu } & , \bar{X}=\text { rata-rata }, & n \text { simpangan baku } \\
d b=\text { derajat bebas } & , \alpha=\text { taraf nyata } &
\end{array}
$$

\subsection{Keterandalan Instrumen Penelitian}

Menurut Kaplan \& Saccuzzo (2005) bahwa metode untuk menduga koefisien kekonsistenan internal menggunakan metode Kuder-Richardson. Metode ini digunakan karena butir-butir pertanyaan berskor dikotomi, yaitu skor 1 atau 0 (jawaban benar atau salah). Rumus Kuder Richardson 21 (KR_21):

$$
\mathrm{KR} \_21=\frac{k}{k-1}\left(1-\frac{\bar{x}(k-\bar{x})}{k \sigma^{2}}\right)
$$

dengan:

KR_21 = koefisien keterandalan menurut Kuder-Richardson 21

$k=$ banyaknya butir pertanyaan 


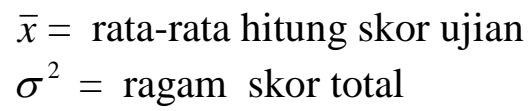

Instrumen penelitian dikatakan andal bila mempunyai nilai KR_21 lebih besar atau sama dengan 0.70 (Kinan, 1990). Menurut Fraenkel \& Wallen (1990) untuk keperluan penelitian nilai koefisien keterandalan seharusnya lebih besar atau sama dengan 0.70 .

\section{Bahan dan Metode}

\subsection{Sumber Data}

Penelitian ini memanfaatkan data sekunder dari hasil Pra-UN 2004/2005 yang dilaksanakan oleh K3SK Jakarta Selatan 06 dan hasil UN 2004/2005 untuk populasi siswa kelas 3 SMEA di Jakarta Selatan 06 bidang studi Matematika. Jumlah SMEA di Jakarta Selatan 06 sebanyak 41 sekolah ( negeri dan swasta ) dengan jumlah total siswa 4898 siswa.

\subsection{Metode Analisis}

Adapun garis besar tahapan analisis data pada pelitian ini adalah sebagai berikut :

a. Menganalisis statistik deskriptif nilai UN siswa tahun akademik 2003/2004 dan tahun akademik 2004/2005

b. Mengelompokkan sekolah menjadi 3 golongan yaitu sekolah dengan mutu baik (golongan 1), sekolah dengan mutu sedang (golongan 2) dan sekolah dengan mutu rendah (golongan 3). Informasi pemilihan mutu sekolah ini didapat dari Dinas Pendidikan Menengah dan Kejuruan DKI, beberapa kepala sekolah dan guru di Jakarta Selatan 06 .

c. Mengidentifikasi banyaknya siswa yang lulus dan siswa yang tidak lulus pada PraUN dan UN untuk : semua sekolah, masing-masing golongan dan masing-masing sekolah dengan membuat tabulasi silang.

d. Menganalisis tabulasi silang dengan uji McNemar (McNemar's test) karena kasus ini merupakan sampel tidak bebas dengan hipotesis :

$H_{0}: P($ lulus pada Pra-UN $)=P($ lulus pada $\mathrm{UN})$

$H_{l}: P($ lulus pada Pra-UN $) \neq P($ lulus pada $\mathrm{UN})$

e. Menentukan batas minimal kelulusan nilai Pra-UN sehingga peluang siswa lulus Pra-UN sama dengan peluang siswa lulus UN untuk semua sekolah dan masingmasing golongan sekolah.

f. Membuat plot antara nilai Pra-UN dan nilai UN untuk semua golongan sekolah dalam satu grafik.

g. Menghitung koefisien korelasi untuk semua sekolah, masing-masing golongan sekolah dan masing-masing sekolah

h. Membuat selang kepercayaan prediksi individual nilai UN

i. Menghitung koefisien keterandalan soal Pra-UN

\section{Hasil dan Pembahasan}

\subsection{Penelusuran Nilai Ujian Nasional Matematika Tahun Akademik 2003/2004 dan 2004/2005}

Pada analisis ini diasumsikan kemampuan siswa dan tingkat kesulitan soal sama untuk kedua tahun akademik tersebut. Berikut ini histogram nilai UN Matematika tahun akademik 2003/2004 dan 2004/2005. 


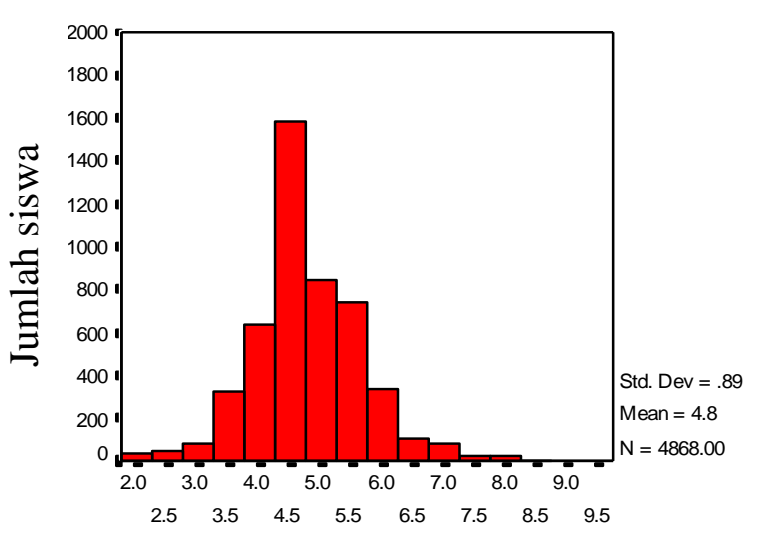

UN

Gambar 1. UN 2003/2004

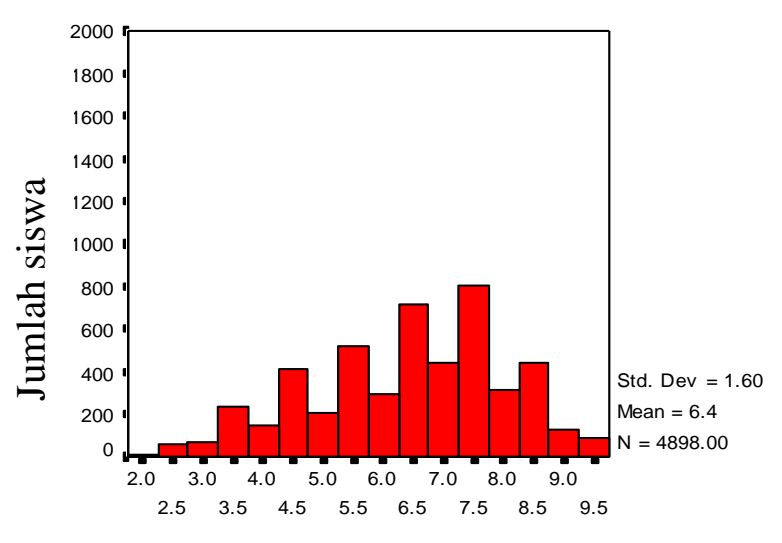

UN

Gambar 2. UN 2004/2005

Pada Gambar 1 dan Gambar 2, distribusi nilai UN tahun akademik 2004/2005 bergeser ke kanan dibandingkan tahun akademik 2003/2004 artinya nilai UN siswa tahun akademik 2004/2005 lebih tinggi dibandingkan tahun akademik 2003/2004. Nilai rata-ratanya juga meningkat dari 4,79 menjadi 6,43. Berikut ini statistik deskriptifnya:

Tabel 3. Statistik deskriptif nilai UN tahun akademik 2003/2004 dan tahun akademik 2004/2005

\begin{tabular}{|l|c|c|}
\hline \multirow{2}{*}{ Statistik } & \multicolumn{2}{|c|}{ Tahun Akademik } \\
\cline { 2 - 3 } Jumlah siswa & $2003 / 2004$ & $2004 / 2005$ \\
Mean & 4868 & 4898 \\
Median & 4,79 & 6,43 \\
Modus & 4,59 & 6,67 \\
Simpangan baku & 4,48 & 7,33 \\
Ragam & 0,89 & 1,60 \\
Skewness & 0,79 & 2,57 \\
Kurtosis & 0,20 & $-0,35$ \\
Minimum & 1,43 & $-0,54$ \\
Maximum & 1,06 & 1,67 \\
Q $_{1}$ & 8,70 & 10,00 \\
$Q_{2}$ & 4,33 & 5,33 \\
$Q_{3}$ & 4,59 & 6,67 \\
\hline
\end{tabular}

Statistik deskriptif pada tabel 3 nilai minimum siswa terjadi peningkatan dari 1.06 menjadi 1.67. Demikian pula nilai maksimumnya meningkat dari 8.70 menjadi 10.00. Nilai koefisien kemenjuluran (skewness) $=0.20$ berarti pola sebaran menjulur ke kanan dengan nilai rata-rata lebih besar dari median. Persentase kelulusan siswa dapat diperhatikan pada tabel 4 berikut ini :

Tabel 4. Persentase kelulusan tahun akademik 2003/2004 dan 2004/2005

\begin{tabular}{|c|c|c|}
\hline \multirow{2}{*}{$\begin{array}{c}\text { Tahun akademik 2003/2004 } \\
\text { dengan batas kelulusan UN =4,01 }\end{array}$} & \multicolumn{2}{|c|}{$\begin{array}{c}\text { Tahun akademik 2004/2005 } \\
\text { dengan batas kelulusan UN }\end{array}$} \\
\cline { 2 - 3 } & 4,01 & 4,26 \\
\hline $89,93 \%$ & $89,59 \%$ & $89,50 \%$ \\
\hline
\end{tabular}


Hasil perhitungan pada Tabel 4, persentase kelulusan siswa tidak terjadi peningkatan bahkan terjadi penurunan walaupun batas kelulusan sama dengan 4,01.

\subsection{Analisis Khi-kuadrat Menggunakan Statistik Uji McNemar}

Uji McNemar digunakan karena kedua sampel tidak bebas. Berikut ini tabulasi silang kelulusan siswa untuk semua sekolah yang dianalisis dengan menggunakan uji McNemar:

Tabel 5. Tabulasi silang kelulusan siswa untuk semua sekolah

\begin{tabular}{|c|c|c|c|}
\hline \multirow{2}{*}{ Pra-UN } & \multicolumn{2}{|c|}{ UN } & \multirow{2}{*}{$\begin{array}{c}\text { Jumlah } \\
\text { Siswa }\end{array}$} \\
\cline { 2 - 3 } & L & TL & 3234 \\
\hline L & 3113 & 121 & 1664 \\
\hline Jumlah siswa & 1271 & 393 & 4898 \\
\hline
\end{tabular}

Keterangan: $\mathrm{L}=$ Lulus $\quad \mathrm{TL}=$ Tidak Lulus

Pada taraf uji 5\% dengan statistik uji McNemar diperoleh nilai $\chi^{2}=950,07$. Nilai ini lebih besar dari $\chi_{0.05: 1}^{2}(3,84)$, artinya hipotesis nol ditolak, yang menunjukkan bahwa secara umum peluang siswa lulus pada Pra-UN tidak sama dengan peluang siswa lulus pada UN. Tabulasi silang untuk masing-masing golongan sekolah adalah sebagai berikut:

Tabel 6. Tabulasi silang kelulusan siswa untuk masing-masing golongan sekolah SMEA golongan 1

SMEA golongan 2

\begin{tabular}{|c|c|c|c|}
\hline \multirow{2}{*}{ Pra-UN } & \multicolumn{2}{|c|}{ UN } & Jumlah \\
\cline { 2 - 3 } L & L & TL & 778 \\
\hline TL & 11 & 1 & 11 \\
\hline $\begin{array}{l}\text { Jumlah } \\
\text { Siswa }\end{array}$ & 788 & 1 & 789 \\
\hline
\end{tabular}

\begin{tabular}{|c|c|c|c|}
\hline \multirow{2}{*}{ Pra-UN } & \multicolumn{2}{|c|}{ UN } & Jumlah \\
\cline { 2 - 3 } L & L & TL & Siswa \\
\hline TL & 437 & 5 & 936 \\
\hline $\begin{array}{l}\text { Jumlah } \\
\text { Siswa }\end{array}$ & 1368 & 8 & 440 \\
\hline
\end{tabular}

$$
\chi_{\text {koreksi }}^{2}=6.75
$$

$$
\chi^{2}=422.23
$$

SMEA golongan 3

\begin{tabular}{|c|c|c|c|}
\hline \multirow{2}{*}{ Pra-UN } & \multicolumn{2}{|c|}{ UN } & \multirow{2}{*}{$\begin{array}{c}\text { Jumlah } \\
\text { Siswa }\end{array}$} \\
\cline { 2 - 4 } L & 1405 & 115 & 1520 \\
\hline TL & 823 & 390 & 1213 \\
\hline $\begin{array}{l}\text { Jumlah } \\
\text { Siswa }\end{array}$ & 2228 & 505 & 2733 \\
\hline
\end{tabular}

Pada ketiga golongan sekolah memberikan kesimpulan yang sama yaitu secara umum peluang siswa lulus pada Pra-UN tidak sama dengan peluang siswa lulus UN. Melihat hasil tersebut, ada dugaan bahwa soal Pra-UN lebih sulit dibandingkan dengan soal UN. 
Berdasarkan Tabel 5 banyak ditemukan siswa yang tidak bisa ditentukan kesiapannya dari hasil Pra-UN, seperti siswa yang tidak lulus Pra-UN ternyata pada UN mereka bisa lulus dengan jumlah yang cukup besar dibandingkan dengan siswa yang lulus pada Pra-UN ternyata gagal pada UN. Ada dugaan bahwa soal Pra-UN lebih sulit dibandingkan dengan soal UN. Berikut ini Statistik deskriptif (Tabel 7) dan histogram nilai Pra-UN dan UN (Gambar 3) untuk semua sekolah :

Tabel 7. Statistik deskriptif nilai Pra-UN dan UN semua sekolah

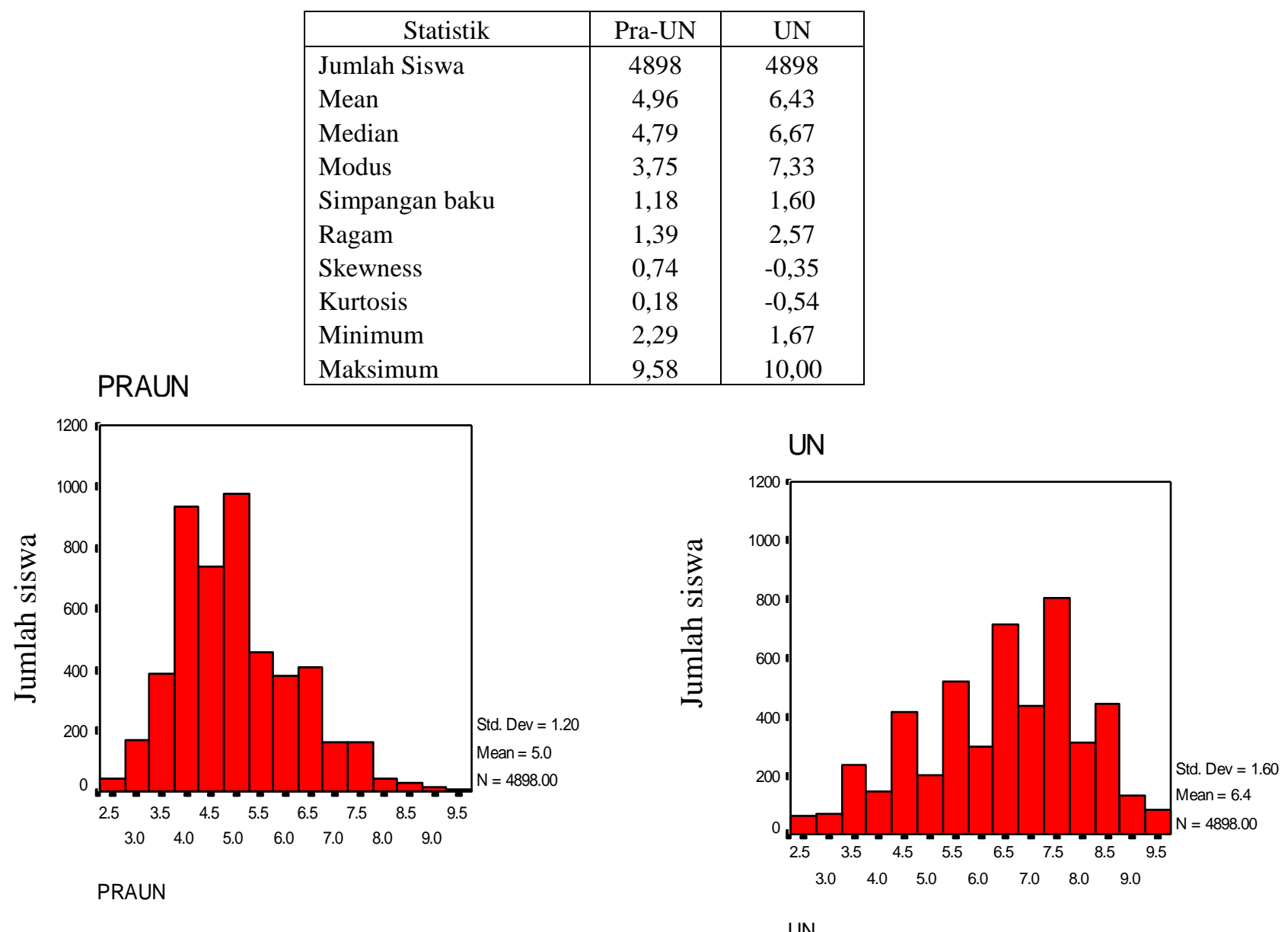

Gambar 3. Histogram nilai Pra-UN dan UN semua sekolah

Hasil ini mengisyaratkan bahwa soal Pra-UN tingkat kesulitan lebih tinggi daripada soal UN. Jumlah butir soal yang berbeda dan alokasi waktu yang sama telah disesuaikan dengan diperbolehkan siswa menggunakan alat hitung pada Pra-UN. Nilai rendah siswa bisa juga disebabkan karena siswa merasa kesulitan menjawab soal Pra-UN akhirnya memaksa menjawab dengan cara menebak.Agar Pra-UN bisa digunakan untuk mengetahui kesiapan siswa dalam menghadapi UN maka batas minimal kelulusan Pra-UN harus diturunkan. Harapannya adalah batas minimal yang diperoleh pada semua sekolah berlaku juga untuk masing-masing golongan sekolah. Berikut ini tabel penurunan batas minimal kelulusan Pra-UN dengan penurunan nilai 0,1 tiap tahap: 
Tabel 8. Pengaruh perubahan batas kelulusan nilai Pra-UN terhadap persentase kelulusan siswa dan nilai khi kuadrat untuk semua sekolah

\begin{tabular}{|c|c|c|c|c|}
\hline $\begin{array}{c}\text { Batas Kelulusan } \\
\text { Pra-UN }\end{array}$ & $\begin{array}{c}\text { Persentase } \\
1 \\
\end{array}$ & $\begin{array}{c}\text { Persentase } \\
2 \\
\end{array}$ & $\begin{array}{l}\text { Nilai Khi- } \\
\text { kuadrat }\end{array}$ & Kesimpulan \\
\hline 4,26 & $96,26 \%$ & $76,38 \%$ & 950,07 & Tolak $\mathrm{H}_{0}$ \\
\hline 4,16 & $95,54 \%$ & $73,35 \%$ & 589,02 & Tolak $\mathrm{H}_{0}$ \\
\hline 4,06 & $95,54 \%$ & $73,35 \%$ & 589,02 & Tolak $\mathrm{H}_{0}$ \\
\hline 3,96 & $94,48 \%$ & $69,25 \%$ & 204,304 & Tolak $\mathrm{H}_{0}$ \\
\hline 3,86 & $94,48 \%$ & $69,25 \%$ & 204,304 & Tolak $\mathrm{H}_{0}$ \\
\hline 3,76 & $94,48 \%$ & $69,22 \%$ & 229,83 & Tolak $\mathrm{H}_{0}$ \\
\hline 3,66 & $93,53 \%$ & $52,50 \%$ & 2,15 & Terima $\mathrm{H}_{0}$ \\
\hline 3,56 & $93,53 \%$ & $52,50 \%$ & 2,15 & Terima $\mathrm{H}_{0}$ \\
\hline 3,46 & $91,42 \%$ & $47,91 \%$ & 177,03 & Tolak $\mathrm{H}_{0}$ \\
\hline 3,36 & $90,84 \%$ & $54,95 \%$ & 207,19 & Tolak $\mathrm{H}_{0}$ \\
\hline
\end{tabular}

Keterangan:

- Persentase 1 adalah persentase siswa yang lulus UN dari yang lulus Pra-UN

- Persentase 2 adalah persentase siswa yang lulus UN dari yang tidak lulus Pra-UN Misal pada batas kelulusan Pra-UN 4,26:

Persentase $1=\frac{3113}{3234} \times 100 \%=96,26 \%, \quad$ Persentase $2=\frac{1271}{1664} \times 100 \%=76,38 \%$

\subsection{Analisis prediksi untuk data hasil Pra-UN dan UN}

Nilai korelasi untuk semua data sama dengan 0,53 dengan nilai koefisien determinasi sama dengan $28,5 \%$, artinya hanya $28.5 \%$ keragaman dari nilai UN yang mampu dijelaskan oleh nilai Pra-UN. Persamaan linier untuk data pada semua SMEA adalah $\mathrm{UN}=2,83+0,73$ PraUN . Prediksi nilai $\mathrm{UN}$ berdasarkan nilai Pra-UN dapat diperhatikan pada Tabel 9 berikut:

Tabel 9. Prediksi nilai UN berdasarkan nilai Pra-UN

\begin{tabular}{|c|c|c|c|}
\hline \multirow{2}{*}{$\begin{array}{c}\text { Pra- } \\
\text { UN }\end{array}$} & \multicolumn{2}{|c|}{ Prediksi } & $\begin{array}{c}\text { Peluang lulus UN } \\
(\mathrm{UN} \geq 4,26)\end{array}$ \\
\cline { 2 - 3 } 2,50 & 4,64 & Selang kepercayaan $95 \%$ & 0,61 \\
2,75 & 4,82 & $(1,98 ; 7,30)$ & 0,66 \\
3,00 & 5,01 & $(2,16 ; 7,49)$ & 0,71 \\
3,25 & 5,19 & $(2,35 ; 7,67)$ & 0,75 \\
3,50 & 5,37 & $(2,53 ; 7,85)$ & 0,79 \\
3,75 & 5,55 & $(2,71 ; 8,03)$ & 0,83 \\
4,00 & 5,73 & $(2,89 ; 8,21)$ & 0,86 \\
4,50 & 6,09 & $(3,07 ; 8,39)$ & 0,91 \\
5,00 & 6,46 & $(3,43 ; 8,75)$ & 0,95 \\
5,50 & 6,82 & $(3,80 ; 9,12)$ & 0,97 \\
6,00 & 7,18 & $(4,16 ; 9,48)$ & 0,98 \\
6,50 & 7,55 & $(4,52 ; 9,84)$ & 0,99 \\
7,00 & 7,91 & $(4,88 ; 10,21)$ & 0,99 \\
8,00 & 8,63 & $(5,25 ; 10,57)$ & 0,99 \\
\hline
\end{tabular}


Nilai-nilai prediksi UN ini semuanya berada diatas 4,26 (batas minimal kelulusan UN) dengan selang kepercayaan $95 \%$ cukup lebar. Dengan lebarnya selang kepercayaan maka makin besar variasi nilai prediksi UN. Misalnya siswa dengan nilai Pra-UN $=2,50$ dengan selang kepercayaan $95 \%$ adalah $(1,98 ; 7,15)$, artinya siswa dengan nilai Pra-UN = 2,50 maka variasi nilai prediksi UN siswa terletak antara 1.98 sampai dengan 7,15. Bila dihitung peluang lulus pada UN siswa dengan nilai Pra-UN $=2,50$ peluang lulus pada UN sama dengan 0,61. Siswa dengan nilai Pra-UN lebih besar atau sama dengan 6,00 memiliki batas bawah selang prediksi UN melebihi batas minimal kelulusan yaitu 4,26 dengan peluang lulus UN diatas 0,97.

\subsection{Analisis Keterandalan Soal Pra-UN}

Analisis ini bertujuan untuk mengetahui andal atau tidak soal Pra-UN, karena banyak ditemukan siswa yang tidak lulus Pra-UN pada UN lulus dan sebaliknya. Seolaholah soal Pra-UN tidak bisa mengukur kemampuan siswa sebenarnya. Pada analisis keterandalan ini hanya dilakukan pada soal Pra-UN. Hal ini dikarenakan penulis kesulitan mendapatkan data UN karena merupakan data rahasia negara. Data UN yang dimaksud yaitu data berskala biner jawaban tiap siswa untuk masing-masing butir soal yang diperlukan dalam analisis keterandalan. Oleh karena itu pada analisis ini diasumsikan bahwa soal UN sudah andal

Nilai koefisien keterandalan (KR_21) soal Pra-UN untuk semua sekolah sama dengan 0,60. Nilai ini lebih kecil dari 0.7 sehingga menurut Kinan (1990) dan Fraenkel \& Wallen (1990) soal Pra-UN ini tidak andal. Namun kriteria tersebut diasumsikan bahwa pengawasan ketat dan penilaian yang jujur. Seandal-andalnya soal Pra-UN bila dalam pelaksanaannya dengan pengawasan tidak ketat dan penilaian yang tidak jujur akan berakibat soal Pra-UN tidak andal. Jadi keterandalan tidak hanya ditentukan oleh butir soal saja melainkan satu rangkaian dengan pelaksanaan Pra-UN diantaranya pengawasan dan penilaian Pra-UN. Data nilai keterandalan untuk ujian-ujian di Indonesia hingga saat ini belum ditemukan berapa rata-rata kriteria yang andal untuk ujian-ujian di Indonesia. Bila seandainya nilai koefisien keterandalan sama dengan 0,5 sudah dikatakan cukup andal untuk ujian di Indonesia, maka perlu diuji apakah nilai KR_21 $=0,6$ sudah andal dengan hipotesa:

$$
\begin{aligned}
& \mathrm{H}_{0}: \rho=0,5 \\
& \mathrm{H}_{1}: \rho>0,5
\end{aligned}
$$

Pada taraf uji 5\% diperoleh $z_{\text {hitung }}=10,07$ yang lebih besar dari $\mathrm{z}_{\text {tabel }}=1,645$ sehingga hipotesis nol ditolak, artinya nilai KR_21 untuk soal Pra-UN lebih besar dari 0,5 atau dengan kata lain soal Pra-UN tersebut andal.

Berdasarkan tabulasi silang kelulusan (tabel 4) banyak ditemukan siswa tidak lulus Pra-UN tetapi UN lulus. Sebaliknya banyak pula ditemukan siswa lulus Pra-UN tetapi UN lulus. sehingga seolah-olah instrumen penelitian,dalam hal ini soal Pra-UN, tidak andal, dengan kata lain Pra-UN tidak dapat memberikan hasil pengukuran yang dapat diandalkan. Dengan demikian hasil tes menjadi tidak memberikan gambaran sesungguhnya dari kemampuan siswa di sekolah. Beberapa faktor kemungkinan penyebabnya adalah sistem ujian, tingkat kesulitan soal dan faktor keseriusan siswa . Dalam Ekaria (2004) ada beberapa faktor yang berperan sehingga hasil ujian tidak memberikan gambaran sesungguhnya kemampuan siswa yaitu : kualitas soal, pengawasan ujian, kesungguhan siswa dalam mengerjakan ujian dan penilaian yang jujur. 


\section{Kesimpulan}

Nilai UN meningkat tetapi tidak diikuti dengan peningkatan persentase kelulusan. Peningkatan nilai UN bisa disebabkan karena kemampuan siswa dan tingkat kesulitan soal yang berbeda dan belum tentu karena Pra-UN.

Kesiapan siswa tidak bisa dilihat dari berhasil atau gagalnya siswa pada PraUN. Secara umum peluang siswa lulus Pra-UN tidak sama dengan peluang siswa lulus pada UN. Siswa lebih besar berpeluang lulus pada UN daripada Pra-UN. Hal ini dikarenakan tingkat kesulitan soal Pra-UN lebih tinggi dibandingkan soal UN dengan batas minimal kelulusan yang sama.

Nilai Pra-UN tidak bisa digunakan sebagai prediksi bagi nilai UN. Hal ini didukung dengan hanya $28,5 \%$ keragaman dari nilai UN yang mampu dijelaskan oleh nilai Pra-UN. Selain itu prediksi nilai UN berdasarkan nilai Pra-UN memiliki selang kepercayaan nilai UN cukup lebar sehingga menyebabkan besarnya variasi prediksi nilai UN.

\section{DAFTAR PUSTAKA}

1. Agresti, A. and Finlay, B., Statistical Methods for the Social Sciences, Third Edition, Macmillan Publishing, Inc., 1986.

2. Ary, D., Jacops, L.C. and Razavieh, A., Introduction to Research in Education, Sixth Edition, Wadsworth Group, 2005.

3. Departemen Pendidikan Nasional: Pendidikan Menengah dan Kejuruan, Laporan Hasil Ujian Nasional SMK 2004/2005, Jakarta, 2005.

4. Draper, N.R. and Smith, H., Applied Regression Analysis, Second Edition, John Wiley \& Sons, Inc., 1981.

5. Ekaria, Analisis Butir Tes Pilihan Ganda dengan Pendekatan Model Item Response Theory (IRT) Tiga Parameter [Tesis], Bogor: Program Pascasarjana, Institut Pertanian Bogor, 2004.

6. Eko, Ujian Akhir Nasional (UAN) Mengapa Perlu, Indocamp, Bekasi, 2005.

7. Fraenkel, J.R. and Wallen, N.E., How to Design and Evaluate Research in Education, Mc.Graw-Hill Publishing Company, 1990.

8. Kaplan, R.M. and Saccuzzo, D.P., Psychological Testing (Principles, Applications, and Issues), Sixth Edition, Wadsworth, A Division Thomson Learning, Inc., 2005.

9. Kinan, S., Beberapa Uji Keterandalan Kuesioner [Skripsi], Bogor: FMIPA, Institut Pertanian Bogor, 1990.

10. Mattjik, A.A. dan Sumertajaya, I.M., Perancangan Percobaan dengan Aplikasi SAS dan MINITAB, Bogor: IPB PRESS, 2000.

11. McNemar, Q., Psychological Statistics, Fourth Edition, John Wiley \& Sons, Inc., 1969.

12. Steel, R.G.D. and Torrie, J.H., Principles and Procedures of Statistics (A Biometrical Approach), Second Edition. McGraw-Hill, Inc., 1980.

13. Sunardi, Keefektifan Program Pengayaan Nonsegregratif pada Prestasi Belajar Siswa Unggul di SMU, Jurnal Ilmu Pendidikan, 2000: 02:125-133.

14. Walpole, R.E. and Myers, R.H., Probability and Statistics for Engineers and Scientists, Fourth Edition, Macmillan Publishing, Inc., 1989. 